\title{
UJI AKTIVITAS ANTIBAKTERI SPONS Plakortis sp. YANG DIKOLEKSI DARI PERAIRAN BUNAKEN
}

\author{
(Antibacterial Activity Test of Sponge Plakortis sp. Collected from \\ Bunaken Waters)
}

\section{Aditya P. Pasodung ${ }^{1 *}$, Fitje Losung ${ }^{1}$, Esther D. Angkouw ${ }^{1}$, Rosita Lintang ${ }^{1}$, Desy M.H. Mantiri ${ }^{1}$, Deiske A. Sumilat ${ }^{1}$}

1. Program Studi IImu Kelautan Fakultas Perikanan dan IImu Kelautan Universitas Sam Ratulangi, Manado.

*e-mail: adityaputrapasodung@gmail.com

Sponges are animals belonging to the phylum of Porifera and one of the animals living on coral reef ecosystems. This organism has been known as a source of various chemical compounds that potentially can be expanded as medicines in marine pharmaceutical field, and antibacterial is one of those compounds. This sponge of Plakortis sp. was obtained from Bunaken Island. The crude extract of the sample was gained by the evaporation then fractionated sample using column chromatography with reversed phase technique. Combination of the solvents used were $\mathrm{dH}_{2} \mathrm{O}: \mathrm{CH}^{3} \mathrm{OH}$ and separated into 6 fractions. Testing of antibacterial analyzation has done by using agar diffusion method from Kirby and Bauer discs. The final results of this study showed that fraction 1, 2, 3, 4, and 6 had antibacterial activity against $E$. coli and $S$. aureus bacterial and fraction 5 had no activity. The two fractions of $S$. aureus have higher activity showed from the inhibitory zone with diameter of fraction 1 was $(16.6 \mathrm{~mm})$, fraction $2(17.3 \mathrm{~mm})$ and the two fractions of $E$. coli have higher activity showed from the inhibitory zone with diameter of fraction 1 was $(17.6 \mathrm{~mm})$ and fraction $2(16.6 \mathrm{~mm})$. This research showed the chemical compounds from Plakortis sp. sponge potentially can be expanded as antibacterial medicine.

Keywords: Sponge, ODS, Chromatography, Antibacterial, Plakortis sp.

Spons merupakan hewan yang termasuk dalam filum Porifera dan salah satu hewan yang hidup pada ekosistem terumbu karang. Biota laut ini diketahui sebagai sumber senyawasenyawa yang berpotensi dalam bidang farmasetika, diantaranya sebagai antibakteri. Sampel spons Plakortis sp. yang diperoleh dari perairan Pulau Bunaken diambil ekstrak kasarnya melalui proses evaporasi lalu difraksinasi dengan teknik reversed phase kromatografi kolom, menggunakan kombinasi pelarut $\mathrm{dH}_{2} \mathrm{O}$ : metanol menjadi 6 fraksi. aktivitas antibakteri dari sampel spons Plakortis sp. terhadap E. coli dan S. aureus dianalisis dengan metode difusi agar. Hasil akhir dari penelitian ini yaitu fraksi 1,2,3,4, dan 6 memiliki aktivitas antibakteri terhadap $E$. coli dan $S$. aureus dan fraksi 5 tidak memiliki aktivitas. Dua fraksi diantaranya memiliki aktivitas tertinggi dengan diameter rata-rata zona hambat yaitu fraksi 1 dengan diameter zona hambat $(16,6 \mathrm{~mm})$, fraksi 2 diameter zona hambat $(17,3 \mathrm{~mm})$ terhadap $S$. aureus, dan untuk E. coli diameter zona hambat fraksi 1 yaitu $(17,6 \mathrm{~mm})$ dan fraksi $2(16,6 \mathrm{~mm})$. Hasil penelitian menunjukkan bahwa senyawa bioaktivitas fraksi ODS spons Plakortis sp. memiliki potensi untuk dikembangkan sebagai obat antibakteri.

Kata Kunci: Spons, ODS, Kromatografi, Antibakteri, Plakortis sp. 


\section{PENDAHULUAN}

Sumber daya alam wilayah daratan sudah banyak diteliti oleh ilmuan untuk diambil manfaatnya bagi kesejahteraan hidup manusia. Mengingat laut tidak hanya berfungsi sebagai sumber cadangan bahan makanan dari berbagai biota laut yang hidup di dalamnya tetapi juga sebagai bahan pembuat kosmetik dan obatobatan. Perairan Bunaken menjadi andalan pemerintah Sulawesi Utara sebagai sumber pendapatan (Wagey, 2017). Terdapat begitu banyak sumber daya alam yang dimiliki, di antaranya biota-biota laut yang berguna untuk dikembangkan sebagai bahan obat, salah satu biota yang potensial adalah spons.

Spons merupakan salah satu biota laut yang sangat prospektif sebagai sumber senyawa bahan-bahan alami antara lain peptida, terpenoid, steroid, asetogenin, alkaloid, halida siklik dan senyawa nitrogen. Senyawasenyawa ini memiliki aktivitas farmakologis seperti antifouling, antitumor, anti-inflamasi, antivirus, antibakteri, dan antimalaria (Kornprobst, 2014). Spons saat ini telah menjadi perhatian utama dalam berbagai riset mengenai senyawa bioaktif antibakteri yang dikandungnya (Undap et al., 2017; Ngantung et al., 2016; Wewengkang dkk., 2014; Bara, 2007). Penelitian ini bertujuan untuk mendapatkan ekstrak kasar spons Plakortis sp. dari Perairan Pulau Bunaken lalu menganalisis aktivitas antibakteri ekstrak spons Plakortis.sp. terhadap bakteri E. colidan $S$. aureus dengan teknik kromatografi kolom.

\section{METODE PENELITIAN}

\section{Waktu dan Tempat Peneletian}

Rangkaian kegiatan penelitian yang meliputi pengambilan sampel, pekerjaan di laboratorium, dan penyusunan laporan dimulai sejak bulan Oktober 2017 dan berlangsung hingga bulan November 2017. Pengambilan dan preparasi sampel dilakukan di perairan Pangalisang Pulau Bunaken, sedangkan pengamatan dan analisis data dilakukan di Laboratorium Biologi Molekuler dan Farmasetika Laut Fakultas Perikanan dan IImu Kelautan Universitas Sam Ratulangi, Manado.

\section{Identifikasi Sampel}

Pengidentifikasian sampel spons dilakukan dengan melihat bentuk, warna, dan struktur spons. Jenis spons ditentukan dengan pencarian melalui buku Biologi Laut (Hooper dan van Soest, 2002). Hasil identifikasi didapatkan ciri-ciri dari spons adalah berwarna hitam, memiliki tekstur lunak dan berwarna kuning di dalamnya.

\section{Alat dan Bahan}

Peralatan yang digunakan pada penelitian ini, antara lain autoklaf, 1 set rotary vacum evaporator, freezedryer, 1 set alat kromatografi kolom, filter paper, micropipete, centrifuge tube, kertas cakram, Timbangan analitik, Mistar.

Bahan yang digunakan adalah agar dextrose kentang, pepton, ekstrak daging (meat extract), dan ODS C-18 untuk pembuatan media cair dan padat B-1 serta bahan lainnya seperti sampel spons Plakortis sp.

\section{Sterilisasi Alat Dan Bahan}

cawan petri, gelas erlenmeyer dan tabung reaksi dicuci bersih dikeringkan lalu dibungkus dengan kertas alumunium foil dan dimasukkan ke dalam oven pada suhu $160^{\circ}$ selama kurang lebih dari 2 jam atau diatutoklaf pada suhu $121^{\circ} \mathrm{C}$ selama 15 menit. Kemudian untuk media cair dan padat B-1, semua bahan dimasukkan dalam gelas erlenmeyer lalu dibungkus dengan alumunium foil kemudian disterilkan dengan autoklaf pada suhu $121^{\circ} \mathrm{C}$ selama 15 menit.

\section{Ekstraksi Spons}

Sampel spons dimaserasi dalam
larutan etanol selama 24 jam 
selanjutnya disaring dengan menggunakan kertas Whattman untuk mendapatkan ekstrak spons. Ekstrak etanol sampel spons kemudian diuapkan dengan rotary vacuum evaporator pada suhu $40^{\circ}$ hingga kering.

\section{Penyiapan Kolom Kromatografi}

Dibuat larutan pencuci sebanyak 4 kosnetrasi yaitu $100 \%$ : $0 \%, 70 \%$ : $30 \%, 50 \%: 50 \%$, dan $0 \%: 100 \%$, bertujuan untuk fase terbalik dan penyesuaian larutan pada kromatografi kolom.

\section{Fraksinasi Spons dengan Kromatografi Kolom}

Sebanyak 5 gram ekstrak sampel diambil lalu diencerkan dengan $10 \mathrm{ml}$ metanol $100 \%$. Kemudian sampel dimasukkan ke dalam kolom menggunakan teknik reversed phase yang sudah berisikan ODS dengan kombinasi pelarut metanol dan aquades. Proses fraksinasi dimulai secara stepwise elution dari $0 \% \mathrm{CH}_{3} \mathrm{OH}$

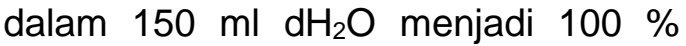
$\mathrm{CH}_{3} \mathrm{OH}$ dan $0 \% \mathrm{dH}_{2} \mathrm{O}$, dengan masingmasing konsentrasi yakni fraksi $1(0 \%$ : $100 \%)$, fraksi 2 (30\%: $70 \%)$, fraksi 3 (50\%: $50 \%$ ), fraksi 4 (65\%: $35 \%)$, fraksi 5 (80\%: $20 \%)$, dan fraksi 6 (100 $\%: 0 \%)$. Untuk pembuatan fraksi-fraksi yaitu diambil 12 gelas erlenmeyer, 6 gelas erlenmeyer dijadikan sebagai wadah fraksi.

\section{Pembuatan Kontrol Positif dan Kontrol Negatif}

Kontrol positif dibuat dari sediaan kapsul kloramfenikol 250 gram yang dilarutkan dalam $100 \mathrm{ml}$ aquades. Sedangkan kontrol negatif menggunakan cairan etanol $95 \%$.

\section{Pembuatan Media Cair B1}

\footnotetext{
Bahan-bahan yang digunakan ditimbang seperti pepton 0,5 gram,
}

ekstrak daging 0,3 gram, $\mathrm{NaCl} 0,3$ gram dimasukkan dalam erlenmeyer lalu ditambahkan aquades $100 \mathrm{ml}$. Erlenmeyer yang telah berisikan bahan diaduk hingga homogen lalu ditutup dengan kertas alumunium foil, kemudian dimasukkan ke dalam autoklaf untuk disterilkan pada suhu $121^{\circ} \mathrm{C}$ selama 15 menit.

\section{Pembuatan Media Padat B1}

Bahan pepton ditimbang sebanyak 1 gram, ekstrak daging 0,6 gram, $\mathrm{NaCl}$ 0,6 gram, agar 3 gram dimasukkan dalam erlenmeyer dan dilarutkan dalam aquades $200 \mathrm{ml}$. Kemudian dibuat homogen menggunakan magnetic stirrer, setelah itu ditutup dan dibungkus menggunakan kertas aluminium foil untuk disterilkan dalam autoklaf pada suhu $121^{\circ} \mathrm{C}$ selama kurang lebih 15 menit.

\section{Pengujian Aktivitas Antibakteri Fraksi-fraksi Sampel}

Pengujian antibakteri Fraksi ODS dari ekstrak spons Plakortis sp. pada penelitian ini menggunakan konsentrasi dari tiap Fraksi yaitu 10 $\mathrm{mg} / \mathrm{ml}$ dan diambil $50 \mu \mathrm{l}$ menggunakan mikropipet untuk ditotolkan pada setiap kertas cakram. Metode yang digunakan pada penelitian ini adalah difusi agar (disc diffusion Kirby and Bauer Method).

\section{Pengamatan dan Pengukuran}

Pengamatan dilakukan setelah 1x24 jam masa inkubasi. Hasil data pengukuran yang diperoleh berupa diameter zona bening dari setiap fraksi ekstrak sampel spons akan diukur menggunakan mistar dan dibandingkan dengan zona bening kontrol positif. Zona bening yang mempunyai diameter paling besar pada umumnya itulah yang lebih berpotensi memiliki aktivitas antimikroba. 
HASIL DAN PEMBAHASAN

\section{Pengambilan Sampel di Lapangan}

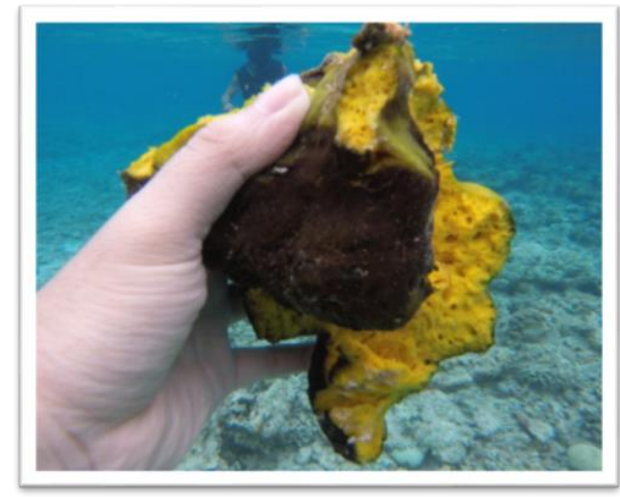

Gambar 1. Spons Plakortis sp. (Dokumentasi pribadi, 2017)

\begin{abstract}
selanjutnya spons dipotongpotong berbentuk dadu/kubus, potongan sampel spons dimasukkan ke dalam botol plastik yang berisikan pelarut etanol $(\mathrm{EtOH})$ sebanyak 250 gram/botol yang telah diberi tanda/label terlebih dahulu (PL1, PL2, dan PL3).
\end{abstract}

\section{Ekstraksi Spons Plakortis sp.}

Ekstrak sampel yang telah diperoleh dari maserasi, kemudian difiltrasi menggunakan filter paper dan vakum. Etanol digunakan karena mempunyai sifat yang selektif, ekonomis, dan mampu mengekstrak sebagian besar senyawa kimia yang terkandung dalam sampel. Setelah dievaporasi diperoleh berat ekstrak kasar spons sebanyak 8,4299 gram.

Tabel 1. Berat botol dan berat hasil

\begin{tabular}{llcc}
\hline No & $\begin{array}{c}\text { Kode } \\
\text { Sampel/Botol }\end{array}$ & $\begin{array}{c}\text { Berat } \\
\text { Botol+Sampel } \\
\text { (gr) }\end{array}$ & $\begin{array}{c}\text { Berat } \\
\text { Basal } \\
\text { Sampel } \\
\text { (gr) }\end{array}$ \\
\hline 1. & PL1 & 402 & 152 \\
\hline 2. & PL 2 & 350 & 100 \\
\hline 3. & PL 3 & 412 & 162 \\
\hline & $\begin{array}{l}\text { Total Berat } \\
\text { Keseluruhan }\end{array}$ & 1,164 & 414 \\
\hline
\end{tabular}

\section{Fraksinasi Spons dengan Kromatografi Kolom}

Proses fraksinasi sampel, diperlukan teknik khusus. Pada penelitian ini, proses fraksinasi ekstrak spons menggunakan alat pemompa angin dan selang, hal tersebut bertujuan untuk memberikan tekanan terhadap pelarut/sampel yang masuk ke dalam kolom sehingga proses fraksinasi bisa sedikit lebih cepat. Terdapat 6 fraksi hasil kromatografi kolom dengan warna yang berbeda. 2 fraksi diantaranya memiliki warna yang hampir sama dengan warna hitam pekat yakni fraksi 1 dan fraksi 2, fraksi 3 berwarna jingga, dan fraksi 4 berwarna jingga pekat,untuk fraksi 5 warnanya terang kecokelatan, sedangkan fraksi 6 agak lebih terang. Perbedaan warna ke-enam fraksi yang diperoleh dari penelitian ini diperkirakan karena ekstrak spons difraksinasi dengan pelarut dan konsentrasi yang berbeda-beda, selain itu keragaman kandungan metabolit sekunder spons seperti peptida, terpenoid, steroid, asetogenin, alkaloid, halida siklik, dan senyawa nitrogen lainnya diperkirakan mempengaruhi perubahan warna tersebut, sama halnya dengan kandungan fitokimia. Teknik pemisahan dengan kromatografi kolom ketika sampel/ekstrak difraksinasi akan mengalami proses seleksi senyawa yang akan mengikuti sifat polaritas.

Tabel 2. Berat kering dari fraksi

\begin{tabular}{lll}
\hline No & $\begin{array}{l}\text { Fraksi-fraksi } \\
\text { Sampel }\end{array}$ & $\begin{array}{c}\text { Berat Kering } \\
\text { Fraksi-fraksi } \\
\text { Spons } \\
\text { Plakortis sp. } \\
\text { (gr) }\end{array}$ \\
\hline 1. & Fraksi 1 & 1,4863 \\
\hline 2. & Fraksi 2 & 0,9705 \\
\hline 3. & Fraksi 3 & 0,8581 \\
\hline 4. & Fraksi 4 & 1,0489 \\
\hline $\mathbf{5 .}$ & Fraksi 5 & 0,7545 \\
\hline 6. & Fraksi 6 & 0,9731 \\
\hline
\end{tabular}




\section{Evaporasi dan Pengeringan Fraksi- fraksi}

Fraksinasi

sampel

menghabiskan waktu yang cukup Panjang, khususnya pada fraksi 1 dan 2 dimana konsentrasi pelarut fraksi 1 dan 2 mengandung paling banyak air/ $\mathrm{dh}_{2} \mathrm{O}$. Juga karena suhu yang digunakan pada proses evaporasi hanya $40^{\circ} \mathrm{C}$ sehingga fraksi yang mengandung banyak air cukup sulit untuk menguap. Setelah proses pengeringan selesai, kemudian fraksi-fraksi sampel ditimbang dengan timbangan analitik untuk mendapatkan berat kering dari setiap fraksi. Berat kering fraksi sampel pada penelitian ini Didapatkan berat yang bervariasi (Tabel 2). Fraksi 1 memiliki berat kering yang paling banyak dibandingkan dengan fraksi lainnya. Hal ini mengindikasikan bahwa ekstrak sampel yang digunakan adalah sampel yang mudah larut dalam air.
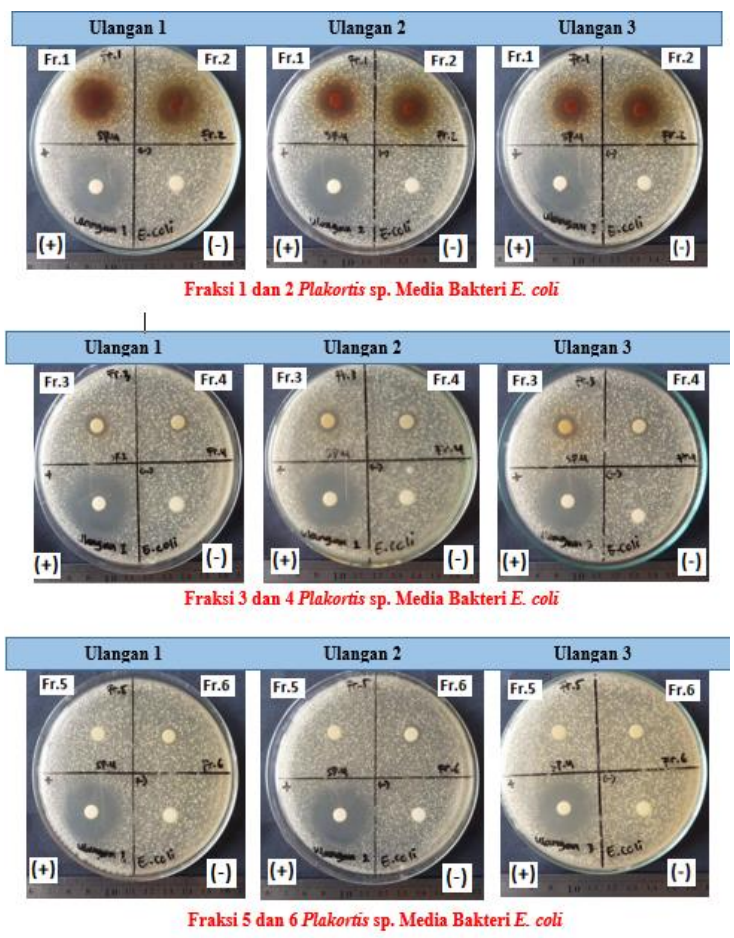

Gambar 2. Spons Plakortis sp pada media bakteri E. coli (Dokumentasi Pribadi, 2017)

\section{Pengujian Aktivitas Antibakteri Spons}

Pengujian aktivitas antibakteri spons Plakortis sp., hasil diperoleh melalui pengamatan yang dilakukan 1x24 jam masa inkubasi dengan 3 kali pengulangan untuk masing-masing fraksi terhadap kedua bakteri uji $E$. coli dan $S$. aureus. Adanya aktivitas antibakteri ditunjukkan dari fraksi 1 hingga fraksi 4 , terhadap bakteri $E$. coli dan $S$. aureus, tetapi fraksi 5 dan 6 tidak memperlihatkan aktivitas/zona hambat, diameter yang dihasilkan setiap fraksi sampel selanjutnya diukur menggunakan mistar dan disalin dalam satuan millimeter ( $\mathrm{mm}$ ). Gambar 2 dan 3 memperlihatkan aktivitas antibakteri fraksi-fraksi sampel terhadap kedua bakteri uji. Nilai rerata pengukuran zona hambat ekstrak spons Plakortis sp.
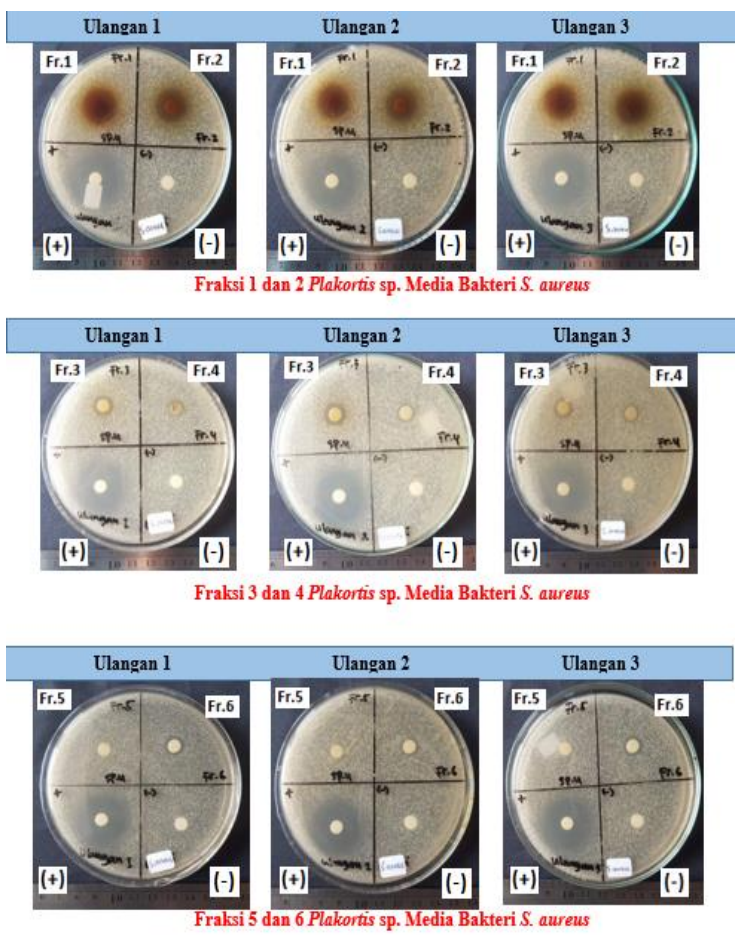

Gambar 3. Spons Plakortis sp pada media bakteri $S$. aureus (Dokumentasi Pribadi, 2017) 
Tabel 3. Hasil pengukuran diameter zona hambat dari spons Plakortis sp.

\begin{tabular}{|c|c|c|c|c|c|}
\hline \multirow{2}{*}{ Fraksi-fraksi } & \multirow{2}{*}{$\begin{array}{l}\text { Berat kering } \\
\text { Fraksi-fraksi }\end{array}$} & \multicolumn{4}{|c|}{$\begin{array}{c}\text { E.coli } \\
\text { Zona hambat }(\mathrm{mm})\end{array}$} \\
\hline & & Ulangan 1 & Ulangan 2 & Ulangan 3 & Rerata \\
\hline Fraksi 1 & gram & 18 & 16 & 16 & 16,6 \\
\hline Fraksi 2 & 0,9705 gram & 17 & 18 & 17 & 17,6 \\
\hline Fraksi 3 & 0,8581 gram & 10 & 10 & 11 & 10,3 \\
\hline Fraksi 4 & 1,0489 gram & 7 & 7 & 8 & 7,3 \\
\hline Fraksi 5 & 0,7545 gram & 0 & 0 & 0 & 0 \\
\hline Fraksi 6 & 0,9731 gram & 6 & 6 & 0 & 4 \\
\hline $\begin{array}{c}\text { Kloramfenikol } \\
(+)\end{array}$ & - & 26 & 26 & 26 & 26,0 \\
\hline $\begin{array}{l}\text { Metanol } \\
(-)\end{array}$ & - & 0 & 0 & 0 & 0,0 \\
\hline \multicolumn{6}{|c|}{$\begin{array}{l}\text { Keterangan: } \\
\text { Konsentrasi pada kertas cakram }=20 \mathrm{mg} / \mathrm{ml} \\
\text { Konsentrasi kontrol positif }=250 \mathrm{mg} / \mathrm{ml} \\
\text { Diameter kertas cakram }=6 \mathrm{~mm} \\
\text { Daya serap kertas cakram }=100 \mu \mathrm{lz} \\
\text { Banyaknya fraksi dalam kertas cakram }=50 \mu \mathrm{l}\end{array}$} \\
\hline
\end{tabular}

Tabel 4. Hasil pengukuran diameter zona hambat dari spons Plakortis sp.

\begin{tabular}{|c|c|c|c|c|c|}
\hline \multirow{2}{*}{ Fraksi-fraksi } & \multirow{2}{*}{$\begin{array}{l}\text { Berat kering } \\
\text { Fraksi-fraksi }\end{array}$} & \multicolumn{4}{|c|}{$\begin{array}{c}\text { S. aureus } \\
\text { Zona hambat }(\mathrm{mm})\end{array}$} \\
\hline & & Ulangan 1 & Ulangan 2 & Ulangan 3 & Rerata \\
\hline Fraksi 1 & 1,4863 gram & 18 & 17 & 18 & 17,6 \\
\hline Fraksi 2 & 0,9705 gram & 16 & 16 & 18 & 16,6 \\
\hline Fraksi 3 & 0,8581 gram & 10 & 12 & 10 & 10,6 \\
\hline Fraksi 4 & 1,0489 gram & 8 & 8 & 8 & 8,0 \\
\hline Fraksi 5 & 0,7545 gram & 0 & 0 & 0 & 0 \\
\hline Fraksi 6 & 0,9731 gram & 7 & 8 & 8 & 7,6 \\
\hline $\begin{array}{c}\text { Kloramfenikol } \\
(+)\end{array}$ & - & 27 & 27 & 27 & 27,0 \\
\hline $\begin{array}{c}\text { Metanol } \\
(-)\end{array}$ & - & 0 & 0 & 0 & 0,0 \\
\hline
\end{tabular}

\section{Keterangan:}

Konsentrasi pada kertas cakram $=20 \mathrm{mg} / \mathrm{ml}$

Konsentrasi kontrol positif $=250 \mathrm{mg} / \mathrm{ml}$

Diameter kertas cakram $=6 \mathrm{~mm}$

Daya serap kertas cakram $=100 \mu \mathrm{l}$

Banyaknya fraksi pada kertas cakram $=\mathbf{5 0} \mu \mathrm{l}$ 
Melalui data yang ditampilkan pada tabel 3 dan 4 menunjukkan bahwa setelah dilakukan pengujian aktivitas antibakteri dari ke-enam ekstrak spons Plakortis sp. terhadap bakteri uji E. coli dan $S$. aureus maka didapatkan diameter zona hambat yang bervariasi. Sehingga Pembuktian ini dapat menjadi suatu terobosan baru dalam penemuan obat antibakteri, dikarenakan sejauh ini pengendalian infeksi bakteri Gram negatif seringkali menjadi kendala dalam dunia kedokteran, yang diakibatkan oleh adanya karakteristik bakteri dari kelompok Gram negatif yang memiliki dinding peptidoglikan yang cukup padat dan kompak serta adanya efflux-pump mechanism yaitu suatu mekanisme untuk mengeluarkan sanyawa-senyawa yang tidak dibutuhkan dalam proses biotransformasi seluler bakteri melalui sistem sekresi, sehingga menghambat proses internalisasi senyawa untuk mampu mempengaruhi mekanisme selular dari bakteri (Posangi et al., 2014; Bara et al., 2015). Selanjutnya data pengukuran diameter zona hambat pada tabel 3 dan 4 dibuat dalam bentuk diagram batang yang disajikan seperti pada gambar 4.

Diperlihatkan bahwa zona hambat spons Plakortis sp. terhadap bakteri $E$. coli memiliki aktivitas antibakteri dengan nilai rerata sebagai daya hambat paling besar diperlihatkan fraksi 1 dan 2, diameter zona hambat fraksi $1(16,6 \mathrm{~mm})$, fraksi $2(17,3 \mathrm{~mm})$, fraksi $3(10,3 \mathrm{~mm})$ fraksi $4(7,3 \mathrm{~mm})$, untuk fraksi 5 (0 $\mathrm{mm} /$ tidak aktif), sedangkan fraksi 6 kembali aktif dengan diameter zona hambat (4 $\mathrm{mm})$. Dibandingkan dengan antibiotik pembanding ekstrak spons Plakortis sp. mempunyai aktivitas zona hambat yang lebih rendah. Sedangkan untuk bakteri $S$. aureus memiliki aktivitas antibakteri dengan nilai rerata sebagai daya hambat paling besar diperlihatkan fraksi 1 dan 2, diameter zona hambat fraksi 1 $(17,6 \mathrm{~mm})$, fraksi $2(16,6 \mathrm{~mm})$, fraksi 3 $(10,3 \mathrm{~mm})$ fraksi $4(8,0 \mathrm{~mm})$, untuk fraksi

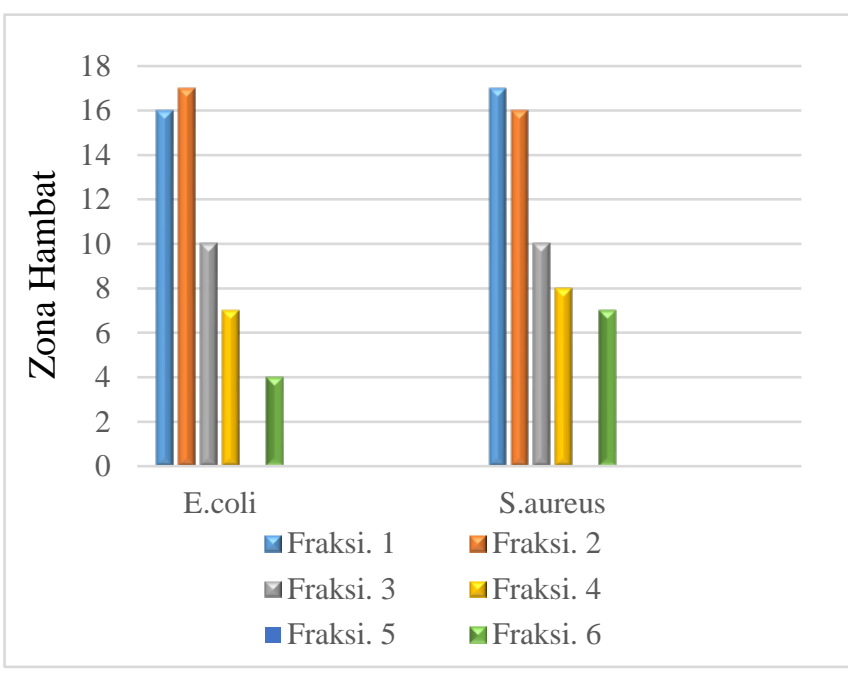

Gambar 4. Diagram rerata diameter zona hambat Spons Plakortis sp. Pada pertumbuhan bakteri E.coli dan S.aureus

5 (0 mm/tidak aktif), sedangkan fraksi 6 kembali aktif dengan diameter zona hambat $(7,6 \mathrm{~mm})$. Dibandingkan dengan antibiotik pembanding ekstrak spons Plakortis sp. Mempunyai aktivitas zona hambat yang lebih rendah sehingga senyawa antibakteri yang terdapat dalam ekstrak ini digolongkan sebagai senyawa/ekstrak yang bersifat sedang/moderate (Patel et al., 2014).

Fraksinasi kromatografi kolom menggunakan bahan ODS terhadap ekstrak spons Plakortis sp. dengan menggunakan kombinasi pelarut $\mathrm{CH}_{3} \mathrm{OH}$ dan $\mathrm{dH}_{2} \mathrm{O}$ menghasilkan senyawa antibakteri yang larut dalam air dan berpotensi membunuh bakteri $S$. aureus dan $E$. coli, kejadian ini didukung dengan data penelitian sebelumnya dari (Luissandy et al., 2017).

\section{KESIMPULAN}

Ada beberapa hal yang disimpulkan dari penelitian ini, yaitu:

1. Ekstrak spons Plakortis sp. berhasil diperoleh sebanyak 8,4299 gram melalui proses maserasi dengan pelarut etanol dan evaporasi.

2. Pemisahan ekstrak kasar spons Plakortis sp. menggunakan teknik (reversed phase) kromatografi kolom 
diperoleh sebanyak 6 fraksi dengan konsentrasi perbandingan metanol dan aquades, dengan berat kering yakni 1,4863 gr. (Fraksi 1), 0,9705 gr. (Fraksi 2), 0,8581 gr. (Fraksi 3), 1,0489 gr. (Fraksi 4), 0,7545 gr. (Fraksi 5), dan 0,9731 gr. (Fraksi 6).

3. Fraksi 1,2,3,4, dan 6 ekstrak spons Plakortis sp. memiliki bioaktivitas antibakteri terhadap pertumbuhan bakteri $E$. coli dengan diameter 16,6 mm (Fraksi 1), 17,3 mm (Fraksi 2), 10,3 mm (Fraksi 3), 7,3 mm (Fraksi 4), dan $4 \mathrm{~mm}$ (Fraksi 6). Kemudian pada bakteri $S$. aureus dengan diameter zona hambat $17,6 \mathrm{~mm}$ (Fraksi 1), 16,6 mm (Fraksi 2), 10,6 $\mathrm{mm}$ (Fraksi 3), 8,0 mm (Fraksi 4), dan 7,6 mm (Fraksi 6).

\section{DAFTAR PUSTAKA}

Bara, R. 2007. Study Metabolic Rate and Metabolism in the Spons Haliclona oculata Using Different ${ }^{13} \mathrm{C} \quad$ Labeled Substrates. Thesis. Wageningen University, Netherlands. p 47.

Bara, R., Kandou, A., Ola, G., Posangi, J. 2015. Analisis Senyawa Antibiotik dari Jamur Simbion Yang Terdapat dalam Ascidians Didemnum molle di Sekitar Perairan Bunaken Sulawesi Utara. Jurnal LPPM Bidang Sains dan Teknologi. 2:28-35

Hooper, J.N.A., Van Soest, R.W.M. 2002. SYSTEMA PORIFERA: $A$ Guide to the Classification of Sponges Volume 1 (Introductions and Demospongia).K1 uwerAcademi c/ Plenum Publishers New York, Boston, London, Moscow. p. 81.

Kornprobst, J. M. 2014. Encyclopedia of Marine Natural Products, Second Edition. Wiley-VCH Verlag GmbH \& Co. 35-57 pp.
Luissandy, D., Sumilat, R., Lintang. 2017. Bioaktivitas Antibakteri Fraksi ODS Spons Agelas sp. dari Perairan Pulau Bunaken. Jurnal Pesisir dan Laut Tropis. 2:25-28.

Ngantung, A.E.C., Bara, R., Sumilat, D.A. 2016. Uji Aktivitas Antibakteri dari Spons Dictyonella funicularis dan Phyllospongia lamellosa yang Diambil pada Perairan Bunaken. Jurnal Pesisir dan Laut Tropis. ISSN: 23391537. 2(1):10-16.

Sumilat, A.D. 2017. Aktivitas Spons Laut Lamellodysidea herbacea dari Perairan Malalayang. Jurnal LPPM Bidang Sains dan Teknologi. ISSN: 2407-6074. 4(1):1-7.

Undap, N.I.J., Sumilat, D.A., Bara, R. 2017. Aktivitas Antibakteri Spons Agelas tubulata dan Phyllospongia sp. dari Perairan Pantai Malalayang Manado Terhadap Pertumbuhan Beberapa Strain Bakteri. Jurnal IImu dan Managemen Perairan. ISSN: 2337-5000. (Accepted). 5(1).

Wewengkang, D.S., Sumilat, D.A., Rotinsulu, H. 2014. Karakterisasi dan Bioaktif Antibakteri Senyawa Spons Haliclona sp. dari Teluk Manado. Jurnal LPPM Bidang Sains dan Teknologi. ISSN: 24076074. 1(1): 71-85.

Wagey, B. 2017. Morphometric analysis of comgeneric seagrasses (Cymodocea rotundata and Cymodocea serrulate) in the coastal areas of Bunaken National Park, North Sulawesi, Indonesia. Faculty of Fisheries and Marine Sience, Sam Ratulangi University. AACL Bioflux, Volume 10, Issue 6. 